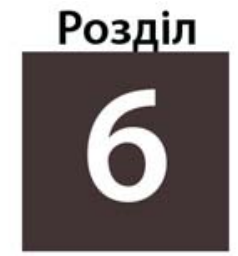

\title{
ПОВІДОМЛЕННЯ
}

УДК 027.54(477-25)НБУВ:341.384:[008:316.752]+271.222(477-25)-77

D0l: $10.15407 /$ rksu.24.329

\begin{abstract}
Lyubov Dubrovina, corresponding member of NAS of Ukraine, Doctor of Historical Sciences, Professor, Director General of V. I. Vernadskyi National Library of Ukraine (Ukraine) ORCID: 0000-0002-1011-7910 e-mail: dubrovina@nbuv.gov.ua

Klaus Gestwa, Ph.D., Professor,

Director of the Institute for East European Studies and Local Lore of the University of Tübingen (Germany) e-mail: klaus.gestwa@uni-tuebingen.de
\end{abstract}

\section{RETURN FROM GERMANY TO UKRAINE OF THE «SOFIAN CHARTER» OF PETER THE GREAT ON THE METROPOLITAN APPOINTMENT OF IOASAPH KROKOVSKYI IN 1708: UKRAINIAN-GERMAN HISTORY OF THE ORIGINAL CHARTER AND PROSPECTS FOR RESTITUTION OF CULTURAL VALUABLES}

Повернення з Німеччини до України «Софійської Грамоти» Петра I митрополитові Іоасафу Кроковському 1708 року: українсько-німецька історія Грамоти та перспективи реституції культурних цінностей

Метою повідомлення $\epsilon$ висвітлення урочистих заходів та німецько-українського наукового колоквіуму, присвяченого поверненню з Німеччини до України Грамоти Петра I митрополиту Іоасафу Кроковському 1708 р. Грамота була вивезена під час Другої світової війни з фондів Національної бібліотеки України імені В. І. Вернадського та перебувала в Інституті Східноєвропейської історії і краєзнавства Тюбінгенського Університету. В колоквіумі брали участь німецькі та українські вчені. Наталія Сінкевич розкрила історичне значення Грамоти, історію створення Грамоти та особистість самого митрополита Іоасафа Кроковського. Тетяна Себта простежила історію Грамоти до 1941 р. та довела її приналежність до колекції Софійського собору, що зберігається в Інституті рукопису Національної бібліотеки України імені В. І. Вернадського. 
Корінна Кур-Королев розслідувала обставини вивезення Грамоти із зібрання Бібліотеки під час Другої світової війни за документами німецьких архівів; Катаріна Кухер розкрила історію надходження Грамоти до Інституту Східноєвропейської історії і краєзнавства Тюбінгенського Університету та роботу експертів із повернення Грамоти. Вольфганг Айхведе поділився досвідом передання до України іншої грамоти Софійської колекції, виданої Петром I митрополитові Варлааму Ясинському 1700 р., а також розповів про повернення картини Ганса фон Маре з Києва до Бремена, в якому брала участь директорка Київського відділення Ґьоте-Інституту графиня Уте Баудіссін. Галина Ковальчук, Ольга Степченко (Київ) приділили увагу історії формування зібрання в Софійському соборі, розкрили унікальний книжковий та рукописний склад цього комплексу, що зберігається в Бібліотеці. Клаус Гества та Любов Дубровіна, підводячи підсумки зустрічі, констатували, що повернення Грамоти $€$ прикладом плідної наукової співпраці вчених Німеччини та України, ефективного вирішення питання стосовно трофейних культурних цінностей, адже місцезнаходження багатьох $з$ них і донині залишається невідомим. Тому важливими $€$ розвиток міжнародного культурного та наукового співробітництва, а також створення Державного реєстру втрачених культурних цінностей.

Ключові слова: трофеї війни, Софійська Грамота Петра I, переміщення культурних цінностей, Друга світова війна, Тюбінгенський Інститут, Національна бібліотека України імені В. І. Вернадського.

The World War II caused the significant destruction of the cultural heritage of different countries, enormous volumes of art, archival and book heritage lost their owners, the centuries-old heritage pieces of many countries were lost to the places of origin and were moved to other countries and collections. Many of them were lost forever. This was especially catastrophic for Ukraine during the $20^{\text {th }}$ century. There are many serious social upheavals and losses of cultural heritage, with both written and printed monuments, as well as book and manuscript collections. The fate of many of them is still unknown.

Although more than 70 years have passed since then, the process of seeking and returning the heritage to the rightful owners has not ceased. Many scientists are working hard searching for those valuables; research is being conducted on archives of different countries; world auctions are being analyzed; personal relationships are being used; public support is gathered from volunteers and the like.

But the return process is extremely complex, it is accompanied by the laborious activities of many people, teams, universities and research organizations, and government institutions. Imperfect legislations also hinders the return of cultural property. For all this time, international organizations, in particular UNESCO, have been making a lot of efforts to develop mutual understanding and harmonize the legislative norms of countries participating in restorative processes. We observe how high-profile restorative processes in the field of the return of artistic heritage are constantly evolving and fall into the field of view of researchers of the history of the Second World War and its consequences.

However, the ongoing search and return of manuscripts and printed heritage, unique archival documents become collector's items in a narrow circle of connoisseurs of history and culture, or accidentally fall into collections due to external signs of antiquity, is much more complicated.

\section{Розділ 6}


Therefore, such rare cases of the return of illegally exported cultural property to libraries in an atmosphere of trust, mutual assistance and professional unification of the efforts of various scientists and governments are so valuable. They inspire us to continue our search and open up new perspectives in scientific relations and creative cooperation between scientists and cultural figures.

On May 30, 2019, an outstanding event of international importance took place at the Institute of Manuscripts of the V. I. Vernadskyi National Library of Ukraine (hereinafter - VNLU) of the National Academy of Sciences of Ukraine, Germany has officially returned the document, a so-called "Sophia Charter», - a certificate of 1708 of the Russian tsar Peter the 1st, on the approval of the Metropolitan of Kyiv Joasaph Krokovskyi. The document was illegally removed from the Ukrainian literary fonds during the World War II. This Charter was delivered to Ukraine and personally accepted by the Minister of Culture Yevhen Nyshchuk. This event became resonant in the cultural life of Ukrainian society.

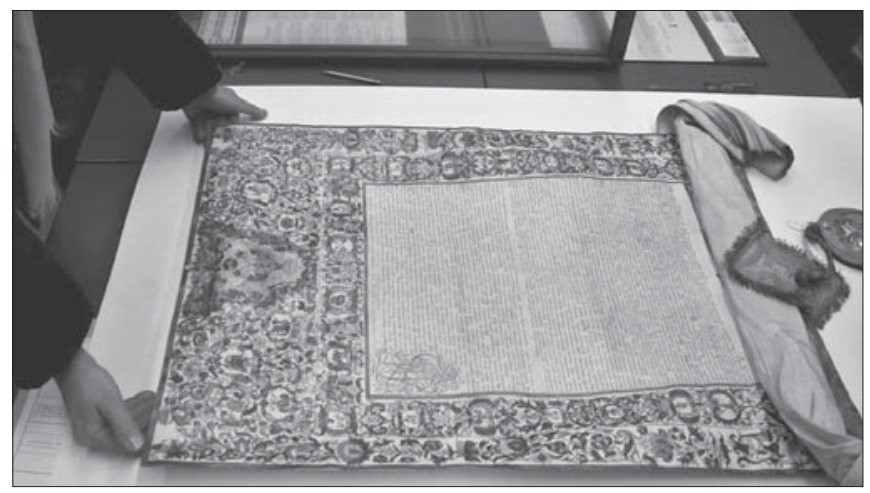

The transfer procedure consisted of several stages. The Charter was handed over on March 14, 2019, at the premises of the Federal Ministry of Foreign Affairs of Germany, where it was handed over by the Secretary of State of the Ministry of Foreign Affairs of Germany Walter Lindner to the Ambassador of Ukraine Andrii Melnyk in the presence of Dr. Michael Jansen, chairman of the German part of the Joint UkrainianGerman Commission on the Return and Restitution of Cultural Property; Dr. Andreas Protman, Head of the Ukrainian Workers' Headquarters of the Foreign Ministry, as well as members of the German-Ukrainian research group. On April 13, 2019, the rarity arrived in Ukraine, which was met by Minister of Culture Yevhen Nyshchuk and Deputy Minister Tamara Mazur. Mrs. Neli Kukovalska, General Director of the Sophia Kyivska National Reserve, accepted and retained the Certificate from the day it was needed in Ukraine. The first public presentation was held at St. Sophia Cathedral on May 24, 2019.

This event was widely covered in the Ukrainian media. Based on the results of the transfer, the V. I. Vernadskyi Library publishes the publication «Diversion to Ukraine of the Charters of Peter loasaph Krokovskyi 1708: Materials of the solemn transfer of the 
Charters and the Ukrainian-German colloquium on May 30, 2019, on the history of the unique document of the Sophia Collection» (Kyiv, 2019) [1]. The book highlights the transfer process, contains statements by officials, reports by German and Ukrainian participants in the colloquium, and discusses the issue of cooperation between scientists and the problems of restorative processes between Germany and Ukraine.

The main credit for this initiative belongs to the Institute for East European Studies and Regional Studies of the University of Tübingen (Institut für Osteuropäische Geschichte und Landeskunde der Eberhard Karls Universität Tübingen). The Charter was discovered there, and a group of his researchers conducted a complete investigation of its origin and fate. In close cooperation with Ukrainian scientists, the owner of the document was established and its transfer to the VNLU organized.

A unique historical document appeared after the World War II in Tübingen, at the Eberhard Karl University of Tübingen (Baden-Württemberg, Germany). Its origin was established thanks to the research of a group of German and Ukrainian experts, about which scientific articles were published in German and Ukrainian periodicals [2].

The rarity was transferred through the initiative of Professor Klaus Gestwa, Director of the Institute for East European Studies and Local History of the University of Tübingen and scientists of the Institute: Dr. Natalya Sinkevych, researcher of the project «Religious knowledge in Early Modern Europe (800-1800)», Dr. Katarina Kucher, Deputy Director Institute, Corinna Kur-Korolev, a former employe of the Institute, and now - the Center for Contemporary History in Potsdam, a famous scientist in the field of cultural values, Professor Wolfgang Eichwede. On the Ukrainian side, Tetyana Sebta, senior researcher at the Institute of Ukrainian Archeography and Source Studies of the National Academy of Sciences of Ukraine, as well as the staff of the National Library's Institute of Manuscript, took part in this process. The latter assisted researchers in finding references and accounting materials on VNLU fonds, prepared their expert opinion for the Ministry of Culture of Ukraine, conducted an additional examination of the origin of the certificate on archival materials of VNLU, in particular, Olga Stepchenko, Olena Halchenko, Svitlana Sokhan, and Marina Philipovych.

The Return of Charter was conducted by the «Joint Ukrainian-German Commission on the Return and Restitution of Cultural Property lost and illegally displaced

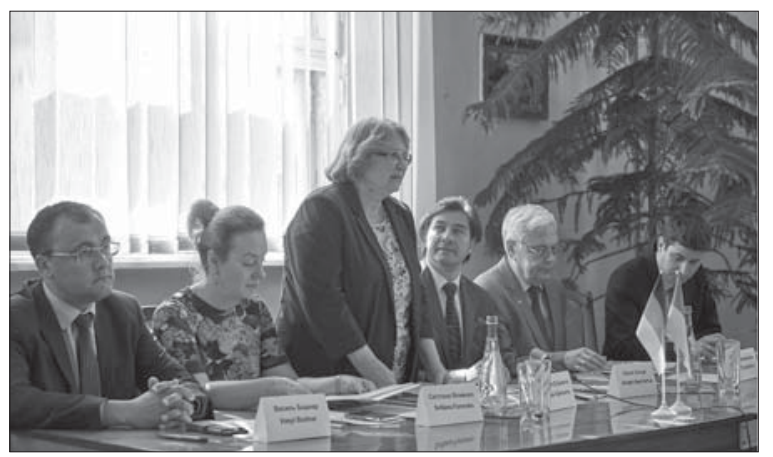
during and as a result of World War \|l», established under the Ministry of Culture of Ukraine. For many years, scientific experts from both sides worked on the Commission. The co-chair of this commission from the Ukrainian side was the First Deputy Minister of Culture of Ukraine Svitlana Fomenko, the cochair from the German side was

\section{Розділ 6}


the Ambassador on Special Assignments, and the retired state secretary, Mr. Michael Jansen, Lyubov Dubrovina, Hennadii Boriak, Serhii Kot, Olena Zhyvkova, Inesa Tatiivska, Tetyana Sebta and Natalia Kashevarova worked as members of the commission and experts. These experts participated also in the colloquiums.

Welcoming speeches were made by Vice President of the National Academy of Sciences of Ukraine, Chairman of the Social and Humanities Sciences Section of the National Academy of Sciences of Ukraine, Academician Serhii Pyrozhkov, Minister of Culture Yevhen Nyshchuk, Deputy Minister of Foreign Affairs of Ukraine Vasyl Bodnar, First Secretary of the Embassy of the Federal Republic of Germany in Ukraine Sebastian Gromig. They noted the importance of the event, the participation of a common team of scientists, scientific institutions, the interaction of the diplomatic circles of Ukraine and Germany, due to which the transfer of the Charter became a good symbol of German-Ukrainian relations. Sincere gratitude was expressed to German and Ukrainian researchers, scientists, Vernadskyi library staff and museum workers.

The transfer involved: Director of the Institute of East European Studies at the University of Tübingen, Professor Klaus Gestwa, Director General of the V. I. Vernadskyi National Library of Ukraine Professor Lyubov Dubrovina, Chairman of the Joint Commission, Deputy Minister of Culture Svitlana Fomenko.

After the celebratory transfer of the Charter, a scientific German-Ukrainian colloquium was held on the history of research and the return of the Charter, as well as a discussion of the restorative process in the field of cultural heritage between our countries. This scientific colloquium was held under the auspices of the Ministry of Foreign Affairs of the Federal Republic of Germany and the National Academy of Sciences of Ukraine, the Ministry of Culture of Ukraine, and the Ministry of Foreign Affairs of Ukraine. The transfer was facilitated by the coordinated interaction of the diplomatic circles of Ukraine and Germany during this lengthy work. This colloquium brought together reputable and well-known scientists of our countries, experts who participated in the study and the return of this historical document, scientists who made a significant contribution to the study of restorative problems, and opened new perspectives in our scientific relations and creative cooperation.

In his speech, Professor Klaus Gestwa, Director of the Institute for East European Studies and Local History of the University of Tübingen emphasized that the transfer of the Charter is a joyful event, the result of quite a long work, as well as the end of the decades of the disappearance of the Charter and its wanderings through the years that ended with a happy return home. He noted that the German-

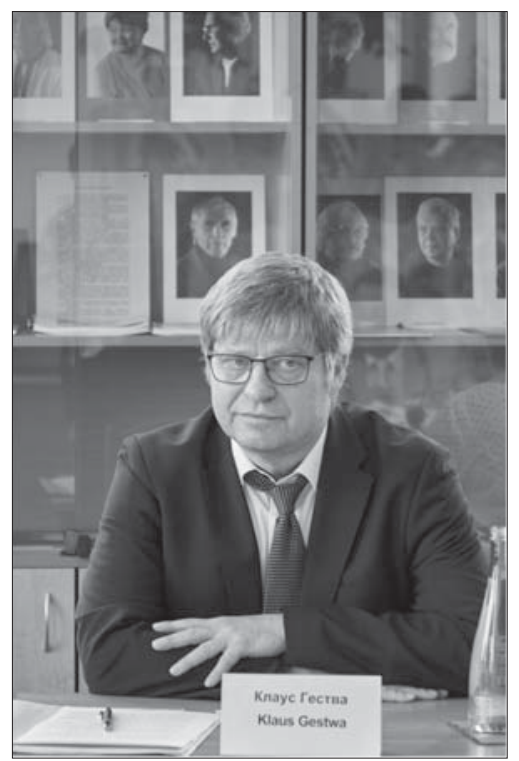


Ukrainian commission worked very actively, experts met in Tübingen, Berlin and Kyiv, carefully examined the archives to find confirmation of the origin of this Charter. This is an example of how to constructively solve complex problems together, and can serve as an example for further solving other complex issues in the return of values. In November 2016, scientists presented a detailed report of their work with a recommendation to return the Charter to Ukraine. The university administration supported this decision and submitted the report to the Baden-Württemberg Ministry of Science, Research and Art for a legal assessment. Based on the evidence and copies presented, Minister Theresa Bauer decided on the restitution of the Charter. These historical decisions have been realised today in Kyiv.

On behalf of the German group of researchers, he expressed gratitude to all participants in the project and high hopes that this example will inspire further research and, possibly, new discoveries. After all, there are still many questions that require investigation.

Welcoming remarks were made by the Director General of VNLU, Corresponding Member of the National Academy of Sciences of Ukraine, Doctor of History, Professor Lyubov Dubrovina. She noted that the transfer of the Charter is an extremely positive moment in the history of the return of lost cultural property. Therefore, a special gratitude was expressed to a group of German and Ukrainian experts, in particular, Professor Klaus Gestwa, and scientists of the Institute, in particular, Dr. Natalia Sinkevych, researcher at the project «Religious knowledge in early modern Europe (800-1800)», Dr. Katarina Kucher, Deputy Director of the Institute for East European Studies, Dr. Corinna Kur-Korolev, a former employee of the Institute, and now - the Center for Contemporary History in Potsdam, known to professor Wolfgang Eichwede On the Ukrainian side, there is Tetyana Sebta, a senior researcher at the Institute of Ukrainian Archeography and Source Studies, as well as VNLU Institute of Manuscript who prepared an official examination of the origin of the Charter for the Ministry of Culture of Ukraine, in particular, Olena Halchenko, Svitlana Sokhan, Marina Philipovych, senior scientific advisers.

A special gratitude was expressed to the co-chair of the German representative office of the Joint Commission - Ambassador on Special Assignments, retired State Secretary Dr. Michael Jansen, who, unfortunately, could not attend this event.

After a short break, a Ukrainian-German colloquium «Designation of Kyiv Metropolitan Joasaph Krokovskyi 1708: Ukrainian-German History of the original Charter of Peter the Great» took place, organized under the patronage of the Ministry of Foreign Affairs of the Federal Republic of Germany and the National Academy of Sciences of Ukraine. The reports of the colloquium shall highlight the results of the study of the Charter, which was covered in detail in a joint article by German and Ukrainian scientists and experts involved in her return - C. Kur-Korolev, K. Kucher, N. Sinkevych, T. Cebta «Trophies of war: history Charters of Peter I and German studios of Eastern Europe exported from Kyiv before and after 1945», published in 2017 in the publication of VNLU «Library Bulletin», No. 1 (URL: http://bv.nbuv.gov.ua/doc/bv_2017_1_8) 
The colloquium was attended by Ukrainian and German specialists and experts who joined the study and the return of this historical document: Professor Klaus Gestva, as well as scientists studying the fate of cultural property during World War II and restitution, primarily Professor Wolfgang Eichwede (Bremen / Berlin), experts and researchers who contributed to the return of the Charter and researched it - Natalia Sinkevych (Kyiv / Tübingen), Dr. Corinna Kur-Korolev (Berlin / Potsdam), Dr. Katarina Kucher (Tübingen), Ph. D (Hist.) Tetyana Sebta (Kyiv), scientists of the VNLU, its Director General Lyubov Dubrovina, Director of the VNLU Institute of Manuscript Ph. D (Hist.) Olga Stepchenko and Director of the Institute of Book Studies Doctor of Historical Sciences Professor Halyna Kovalchuk (Kyiv), and others.

Natalia Sinkevych, who is honored to be the first to reveal the origin of the Charter, highlighted the historical significance of the Charter, told the story of the Charter and the outstanding personality of Metropolitan Joasaph Krokovsky himself, the last elected Metropolitan of Ukraine, associate of the Hetman of Ukraine Ivan Mazepa. She talked about his life and contribution to the religious life of Ukraine.

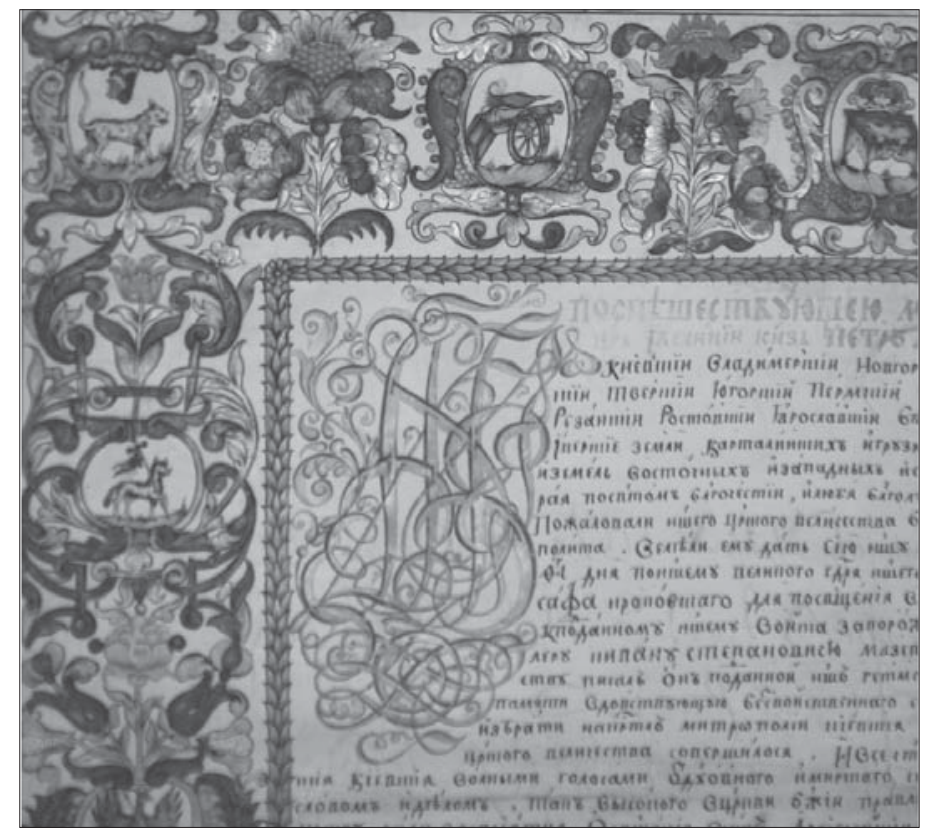

Tetyana Cebta revealed the history of the Charter until 1941 and proved it's belonging to the collection of St. Sophia Cathedral, which was nationalized after the revolution of 1917-1918. Its collection passed into the jurisdiction of the National Library of Ukraine (since 1934 - the Library of the Academy of Sciences of the Ukrainian SSR, now the V. I. Vernadskyi National Library of Ukraine). She relied on documents from the archives of the VNLU Institute of Manuscript, established the composition of the Charters of the Cathedral, among which was a Charter to Joasaph Krokovskyi, her previous studies and publication by Metropolitan Evhen Bolkhovitinov in 1825 [3, p. 110-113]. 
Corinna Kur-Korolev investigated the circumstances of the export of the Diploma from the Library, worked in the archives of Germany, primarily in the Political Archive of the Ministry of Foreign Affairs. She suggested that the Library was burglarized by the Künsberg's Sonderkommando or other SS representatives who were in Kyiv at that time. Perhaps, for example, Hans Koch, Wilfried Krallert, Victor Paulsen, people who knew a lot about the value of the Charter. The Charter was taken out either in October 1941 or in October 1943 by transport organized by Georg Winter. The lack of information about the Charter in official documents indicates the private nature of the export of the Charter.

Katarina Kucher revealed the history of the Charter at the Tübingen Institute for East European History and Local History, where she was transferred by Professor Werner Markert, founder and first director of the University of Tübingen. According to him, he bought a Charter from a second-hand book dealer for 2000 deutschmarks, but in fact it cannot be ruled out that he took it out in October 1943, when he was there in the Künsberg's Sonderkommando. Krallert also sold geographic maps to the University, which may have also been from a warehouse confiscated by Künsberg.

Wolfgang Eichwede told the story of the transfer of another Charter from the Sofia collection, issued by Peter the Great in 1700 to Metropolitan Varlaam Yasynskyi. Eichwede was a participant in the program with the help of the director of the Kyiv branch of the Goethe Institute Countess Ute Baudissin. Countess Baudissin obtained it from a war veteran, American soldier William Galen, who took it as a trophy at the SS premises in Vienna. Many years later, he found out that this was the original of Peter the Great's Charter and returned it with the help of Countess and Wolfgang Eichwede to Kyiv. Unfortunately, at the time it was not known that this Charter was from a collection stored in the V. I. Vernadskyi Library, so it ended up in the fonds of the Central State Historical Museum in Kyiv. He also recalled the transfer of the painting by Hans von Mare from Kyiv to Bremen, thanks to the wishes of the owner, who wanted to return the painting. Wolfgang Eichwede emphasized the importance of personal relations of researchers in search of lost cultural artifacts.

Galyna Kovalchuk and Olga Stepchenko recalled that the history of confiscation and removal of library fonds was first described by the historians of the Library L. A. Dubrovina, N. I. Maloletova and O. S. Onyshchenko [4, p. 54-60]. The speakers focused on the history of the formation of the collection in St. Sophia Cathedral, and revealed the contents of the unique book collection. Books were collected by the highest church hierarchs of the Orthodox Church in Ukraine, since St. Sophia Cathedral was the residence of the Kyiv Metropolitans. The entry of the St. Sophia collection into the Library is also described in the book by L. A. Dubrovina and O. S. Onyshchenko [5, p. 156, 188]. The collection consists of Cyrillic old-printed and rare editions, including the first editions of Ukrainian religious writers of the $16^{\text {th }}-18^{\text {th }}$ centuries (as of 1924 there were 1560 old-printed in Cyrillic and Latin, and today are 1795 books), the works of the Metropolitans themselves. In 1924, the composition of the St. Sophia Cathedral was disclosed in an article by V. I. Barvynok [6].

\section{Розділ 6}


Manuscript collections of the St. Sophia Monastery at the VNLU was represented by Lyudmila Hnatenko in the reference book of the VNLU Institute of Manuscript [7, p. 133-144]. Today, the manuscript collection consists of 1051 units of historical Charters and documents. The connection of the Charter with the fonds of this collection was shown by Olga Stepchenko, who introduced the exhibition of these certificates, which was demonstrated in the hall where the colloquium was held. Other documents and the expert opinion of the Institute of Manuscript prepared for the Ministry of Culture of Ukraine were also demonstrated.

Scientists, members of the Joint Commission and experts discussed the results of the colloquium. They discussed issues related to the transfer of the Charter, other valuable items in the return of captured cultural property, the activities of the Department of the Ministry of Culture for the Displacement of Cultural Property and the Joint Ukrainian-German Commission on the Return and Restitution of Cultural Property of the Ministry of Culture of Ukraine, problems and prospects for further work. Among them, experts and members of the Joint Ukrainian-German Commission on the Return and Restitution of Cultural Valuables:

Lyubov Dubrovina, Professor, Doctor of Historical Sciences, Corresponding Member of the NAS of Ukraine, General Director of the V. I. Vernadskyi National Library of Ukraine, member of the Joint Ukrainian-German Commission.

Inesa Tatiivska, Ph. D. (Hist.), Deputy Head of the Department for the Displacement of Cultural Property of the Ministry of Culture of Ukraine, member of the Joint Ukrainian-German Commission.

Hennadii Boryak, Professor, Doctor of Historical Sciences, Corresponding Member of the NAS of Ukraine, Deputy Director of the Institute of History of Ukraine of the NAS of Ukraine, member of the Joint Ukrainian-German Commission.

Sergii Kot, Professor, Doctor of Historical Sciences, Head of the Center for Research on the Historical and Cultural Heritage of Ukraine of the Department of History of Ukraine of the second half of the $20^{\text {th }}$ century, Institute of History of Ukraine, NAS of Ukraine, member of the Joint Ukrainian-German Commission.

Oleksii Onyshchenko, Academician of the NAS of Ukraine, Advisor to the Presidium of the NAS of Ukraine, Chief Scientific Officer of the VNLU, Honorary Director General of VNLU, researcher of the history of cultural values and library science in the $20^{\text {th }}$ century.

Maryna Palienko, Professor, Doctor of Historical Sciences, Head of the Department of Archival Studies and Special Branches of historical science of Taras Shevchenko Kyiv National University, researcher of the history of archival heritage of Ukraine, expert on the history of cultural values.

Nataliya Kashevarova, Ph. D. (Hist.), Senior Researcher at the Institute of History of Ukraine, National Academy of Sciences of Ukraine, researcher on the history of the displacement of cultural property, an expert on the history of cultural property during the Second World War. 
Olena Zhyvkova, Deputy Director General for research at the Bogdan and Varvara Khanenko National Museum of Art in Kyiv, member of the Joint Ukrainian-German Commission.

During the transfer of the Charter and the work of the colloquium in the VNLU hall, a collection of Charters on the difference of the St. Sophia Monastery, stored in the manuscript and book collection of the St. Sophia Monastery, was presented. The guests and participants of the colloquium were also shown unique documents from the collection of the St. Sophia Monastery, an interesting sightseeing tour of the historical building of the Library was conducted, and some rarities were shown, including unique historical and cultural fonds: manuscripts, old-printed and rare editions, book collections and collections, musical and fine foundations. In the Music Room, they listened to the Ludwig Beethoven Appathion performed by a young pianist, Anton Labik-Pronyuk, who at the age of 14 was already a laureate of international and domestic pianist competitions.

The discussion of restitution was interesting. The circumstances of the transfer of the Charter became one of the examples of fruitful scientific cooperation between scientists from Germany and Ukraine, a sincere desire to return the unique Charter of 1708 to the collection, where it was preserved until the Second World War - the V. I. Vernadsky National Library of Ukraine. The transfer procedure provides for documented studies of the origin of the cultural property and the circumstances of its export. These studies should be attended by highly professional historians who possess the subject of research and knowledge of languages and can work in a team where there is an atmosphere of creative freedom and trust.

The activities of joint teams of scientists and cultural figures from different countries can effectively solve the issue of the return of captured cultural values, in spirit of full support of state government agencies and diplomatic services, as well as the general public, which understands the need to establish justice and return cultural property to the owners.

All this is especially important, considering that many cultural values are in personal and private collections today. Experience shows that today the origin of many trophy materials purchased after the war in antique stores, at auctions and antiquity markets for museum collections still remain unknown to museum staff. Therefore, the search for cultural properties through online acquaintance with collections and collections, through informal communication and contacts between scientists and cultural figures, development before international cultural and scientific cooperation is also important.

However, until Ukraine creates the State Registry of Lost Cultural Property, this work will demonstrate only the isolated efforts of conscious scientists and still be although very important, but random finds.

\section{Розділ 6}




\section{References}

1. Povernennia v Ukrainu hramoty Petra I loasafu Krokovskomu 1708 r.: materialy urochystoho peredannia Hramoty ta ukrainsko-nimetskoho kolokviumu 30 travnia 2019 r. $z$ istorii unikalnoho dokumenta Sofiiskoi kolektsii [The returning to Ukraine of the Peter the First Charter to Joasaph Krokovskyi, 1708: Materials of the solemn transfer of the Charter and Ukrainian-German colloquium on May 30, 2019, on the history of the unique dokument from St. Sophia collection]. (2019). L. Dubrovina, T. Arseienko, Z. Sharikova (Comps.). [In Ukrainian].

2. Kur-Korolev, K., Kukher, K., Sinkevych, N., Sebta, T. Trofei viiny: istoriia vyvezenoi z Kyieva hramoty Petra I ta nimetski studii Sxidnoi Yevropy do I pislia 1945 r. [Tropheis of war: a history of the Peter the First Charter exported from Kyiv and German Sudies on the East Europe before and after 1945]. (2017). In Bibliotechnyi visnyk [Library Bulletin]. No. 1. Retrieved from: http://bv.nbuv.gov.ua/doc/bv_2017_1_8 [In Ukrainian].

3. Bolkhovitinov, Ye. Opisanie Kievo-Sofiiskogo sobora i Kievskoi yerarkhii [Description of the Kyiv St. Sophia Cathedral and Kyiv episcopy]. (1825). Part 2. Kyiv. [In Russian].

4. Dubrovina, L. A., Onyshchenko, O. S. Istoriia Natsionalnoi biblioteky Ukrainy imeni V. I. Vernadskoho. 1941-1964 [History of V. I. Vernadskyi National Library of Ukraine. 19411964]. (2003). Kyiv. [In Ukrainian].

5. Dubrovina, L. A., Onyshchenko, O. S. Istoriia Natsionalnoi biblioteky Ukrainy imeni V. I. Vernadskoho. 1918-1941 [History of V. I. Vernadskyi National Library of Ukraine. 1918-1941].(1998). Kyiv. [In Ukrainian].

6. Barvinok, V, I, Zahalnyi ohliad starodrukiv kyivskykh bibliotek [General review of the early printed book in Kyiv libraries]. (1924). In Bibliolohichni visti [Bibliological news]. Kyiv. [In Ukrainian].

7. Hnatenko, L. Zibrannia rukopysnykh knyh ta arkhiv Sofiiskoho soboru [Collection of manuscripts and archives of the St. Sophia Cathedral]. (2015). In Arkhivy, kolektsii ta zibrannia derzhavnykh, hromadskykh ta relihiinykh ustanov u fondakh Instytutu rukopysu Natsionalnoi Biblioteky Ukrainy imeni V. I. Vernadskoho. Putivnyk [Archives and collections of the state, public and religious institutions in the fonds of Institute of Manuscript of V. I. Vernadskyi National Library of Ukraine. Fonds' Guide]. Kyiv. [In Ukrainian]. 


\section{Lyubov Dubrovina,}

corresponding member of NAS of Ukraine,

Doctor of Historical Sciences, Professor,

Director General of V. I. Vernadskyi National Library of Ukraine (Ukraine)

ORCID: 0000-0002-1011-7910

e-mail: dubrovina@nbuv.gov.ua

\section{Klaus Gestwa,}

Ph.D., Professor,

Director of the Institute

for East European Studies and Local Lore

of the University of Tübingen (Germany)

e-mail: klaus.gestwa@uni-tuebingen.de

Return from Germany to Ukraine of the "Sofian Charter» of Peter the Great on the metropolitan appointment of loasaph Krokovskyi in 1708: Ukrainian-German history of the original Charter and prospects for restitution of cultural valuables

The goal of the article is to cover the ceremony and the German-Ukrainian scientific colloquium dedicated to the return from Germany to Ukraine of the Charter of tsar Peter the Great, on the appointment of Metropolitan Joasaph Krokovskyi in 1708. The Charter was taken from the fonds of the V. I. Vernadskyi Library during World War II and ended up at the Institute of East European History and Local History of Tubingen University. The colloquium was attended by German and Ukrainian scientists. Natalia Sinkevich revealed the historical significance of the Charter, the history of the Charter and the personality of Metropolitan Joasaph Krokovskyi himself. Tetyana Cebta traced the history of the Charter to 1941 and proved her belonging to the collection of St. Sophia Cathedral, stored at the Institute of Manuscript of the V. I. Vernadskyi National Library of Ukraine. Korinna Kur-Korolev investigated the circumstances of the export of Charters from the library during the Second World War according to the documents of the German archives; Katarina Kucher revealed the history of the Charter at the Institute of East European History and Local History of Tubingen University and the work of experts on the return of the diploma. Wolfgang Eichwede shared the experience of transferring another Charter of the St. Sophia collection, issued by Peter the Great in 1700 to Metropolitan Varlaam Yasynskyi, together with the director of the Goethe Institute Kyiv branch, Countess Ute Baudissin, the return of the painting by Hans von Mare from Kyiv to Bremen. Halyna Kovalchuk, Olga Stepchenko (Kyiv) brought attention to the history of the formation of the collection in St. Sophia Cathedral, disclosed the contents of the unique book and manuscript collection stored in the V. I. Vernadskyi Library. Klaus Gestwa and Lyubov Dubrovina discussed the results of the research of the Charter. The Return of the Charter is an example of fruitful scientific cooperation between scientists from Germany and Ukraine, an effective solution to the issue of the return of expropriated cultural values. 
The location of many expropriated materials remains unknown today. Therefore, it is important to develop international cultural and scientific cooperation, and the creation of the State Registry of Lost Cultural Property.

Keywords: St. Sophia Charter of Peter the Great, displacement of cultural property, World War II, Institute of East European History and Local History of Tubingen University, V. I. Vernadskyi National Library of Ukraine.

\section{Любовь Андреевна Дубровина,}

член-корреспондент НАН Украины, доктор исторических наук, профессор,

Генеральный директор Начиональной библиотеки

Украины имени В. И. Вернадского (Украина)

ORCID: 0000-0002-1011-7910

e-mail: dubrovina@nbuv.gov.ua

\section{Клаус Гества,}

Ph.D., профессор Института Восточноевропейской истории и

краеведения Тюбингенского Университета (Германия)

e-mail: klaus.gestwa@uni-tuebingen.de

Возвращение из Германии в Украину «Софийской Грамоты» Петра I митрополиту Иоасафу Кроковскому 1708 года: украинско-немецкая история Грамоты и перспективы реституции культурных ценностей

Целью сообщения является освещение торжественных мероприятий и немецко-украинского научного коллоквиума, посвященного возвращению из Германии в Украину Грамоты Петра I митрополиту Иоасафу Кроковскому в 1708 г. Грамота была вывезена во время Второй мировой войны из фондов Национальной библиотеки Украины имени В. И. Вернадского и оказалась в Институте Восточноевропейской истории и краеведения Тюбингенского Университета. В коллоквиуме участвовали немецкие и украинские ученые. Наталья Синкевич раскрыла историческое значение Грамоты, историю создания Грамоты и личность самого митрополита Иоасафа Кроковского. Татьяна Себта проследила историю Грамоты до 1941 г. и доказала ее принадлежность к коллекции Софийского собора, хранящейся в Институте рукописи Национальной библиотеки Украины имени В. И. Вернадского. Коринна КурКоролев расследовала обстоятельства вывоза Грамоты из собрания Библиотеки во время Второй мировой войны по документам немецких архивов; Катарина Кухер раскрыла историю поступления Грамоты в Институт Восточной истории и краеведения Тюбингенского Университета и работу экспертов по возвращению Грамоты. Вольфганг Айхведе поделился опытом передачи в Украину другой грамоты Софийской коллекции, выданной Петром I митрополиту Варлааму Ясинскому в 1700 г., а также рассказал о возвращении картины Ганса фон Маре из Киева в Бремен, 
в котором принимала участие директор Киевского отделения Гете-Института графиня Уте Баудиссин. Галина Ковальчук, Ольга Степченко (Киев) уделили внимание истории формирования собрания в Софийском соборе, раскрыли уникальный книжный и рукописный состав этого комплекса, хранящейся в Библиотеке. Клаус Гества и Любовь Дубровина, подводя результаты встречи, констатировали, что возвращение Грамоты является примером плодотворного научного сотрудничества ученых Германии и Украины, эффективного решения вопроса относительно трофейных культурных ценностей, исходя из того, что местонахождение многих трофейных материалов и ныне остается неизвестным. Поэтому важным являются развитие международного культурного и научного сотрудничества, а также создание Государственного реестра утраченных культурных ценностей.

Ключевые слова: Софийская Грамота Петра I, перемещение культурных ценностей, Вторая мировая война, Институт Восточноевропейской истории и краеведения Тюбингенского Университета, Национальная библиотека Украины имени В. И. Вернадского. 